\title{
USING THE BARKHAUSEN-NOISE ANALYSIS AND METAL-MAGNETIC-MEMORY METHOD FOR MATERIAL CHARACTERISTICS UNDER FATIGUE DAMAGE
}

\author{
UPORABA METODE BARKHAUSNOVEGA HRUPA IN \\ MAGNETNEGA SPOMINA ZA KARAKTERIZACIJO \\ UTRUJENOSTNIH POŠKODB MATERIALA
}

\author{
Kamil Kolařík ${ }^{1}$, Jiří Šimeček ${ }^{1}$, Antonín Kř̌iž ${ }^{1}$, Jiří Čapek ${ }^{2}$ \\ ${ }^{1}$ University of West Bohemia, Faculty of Mechanical Engineering, Univerzitení 8, 30100 Plzeň, Czech Republic \\ ${ }^{2}$ Czech Technical University, Faculty of Nuclear Sciences and Physical Engineering, Trojanova 13, 12000 Prague, Czech Republic \\ kamil.kolarik@email.cz
}

Prejem rokopisa - received: 2016-03-30; sprejem za objavo - accepted for publication: 2016-06-09

doi:10.17222/mit.2016.056

\begin{abstract}
The article deals with process monitoring and the subsequent diagnosis of fatigue damage during material testing of steel S355. The study was performed by means of the metal-magnetic-memory method, Barkhausen-noise analysis and X-ray diffraction. This combination could significantly enhance the inspection quality of critical mechanical-unit parts during their lifespan. X-ray diffraction was applied for the description of the state of residual stresses, in combination with the Barkhausen-noise analysis, which allows us to immediately determine the changes in the surface layer resulting from the residual-stress redistribution, hardness and potential microcracks. Additionally, a new unconventional method for the determination of the stress-concentration-zone location and for the detection of material defects and imperfections, the so-called metal-magnetic-memory method, will be introduced.

Keywords: Barkhausen noise, metal-magnetic-memory method, X-ray diffraction, fatigue damage
\end{abstract}

Članek obravnava proces kontrole, in iz tega naknadno diagnozo utrujenostne poškodbe, med preizkusom materiala, jekla S355. Študija je bila izvedena s pomočjo metode magnetnega spomina kovine, z Barkhausnovo analizo hrupa in z rentgensko difrakcijo. Ta kombinacija lahko občutno izboljša kvaliteto kontrole kritičnih mehanskih komponent med njihovo življenjsko dobo. Rentgenska difrakcija je bila uporabljena za opis stanja zaostalih napetosti, v kombinaciji z analizo Barkhausnovega hrupa, kar omogoča takojšnje določanje sprememb v površinski plasti, kar je posledica prerazporeditve zaostalih napetosti, trdote in potencialnih mikrorazpok. Dodatno bo predstavljena nova neobičajna metoda za določanje področij koncentriranja napetosti ter za odkrivanje napak in nepravilnosti, imenovana metoda magnetnega spomina kovine.

Ključne besede: Barkhausnov hrup, metoda magnetnega spomina kovin, rentgenska difrakcija, utrujenostna poškodba

\section{INTRODUCTION}

Characteristics of all machine components depend on the final surface quality ${ }^{1}$ and surface material layers, namely the residual-stress (RS) distribution and the roughness. These properties involve functionality and durability, especially fatigue life. The surface of an engineering component is a sensitive part, especially because of the interface between the component and the external environment. The surface layers of the material are damaged by the transmitted working load and other degradative effects such as vibrations, radiant energy, chemical influences (rust), etc. In general, it is known that more than $90 \%$ of the operating-part fractures are caused by fatigue. ${ }^{2}$

Material fatigue is a process (a change in mechanical properties, creation of a microcrack net, growth of the maximum crack and workpiece fracture), which gradually deplete the utility properties of a product until a fracture of the workpiece and irreversible damage occur. ${ }^{3}$ Currently, the process of crack formation can only be observed if we use non-destructive testing me- thods such as ultrasonic testing, magnetic particle inspection, industrial radiography and capillary testing. These methods detect only incurred cracks and defects, but they are not able to register the initialization of cracks. ${ }^{4}$

Recently, it was suggested that this drawback could be eliminated with a combination of the Barkhausennoise analysis $(\mathrm{BNA})^{5,6}$ and the metal-magnetic-memory method (MMM) ${ }^{7,8}$ Based on different signal inception depths, a combination of these methods can provide a substantial financial reduction thanks to a faster response and cheaper control of a potentially critical point achievement. In addition, for a description of particular surface stages (especially the level of residual stresses in test samples before and after the loading), the mentioned magnetic methods should be supplemented with the results obtained with the X-ray diffraction technique. ${ }^{9,10}$

The principle of the BNA has been known for many years and used in diagnostics of machined layers. ${ }^{11}$ The MMM method is based on the magneto-elasticity and magneto-mechanical effect theory. ${ }^{12,13}$ Due to the 
self-magnetization phenomenon of ferromagnetic materials, during the operation of equipment, the magnetic field is kept down when the work load is off. The residual magnetic field is related to the mechanical stress, that is, the residual magnetic field density $\mathrm{Hp}$ is characterized by the polarity varying along the normal. Thus, using the MMM testing instrument, the most serious zones of a stress concentration (SZC), defects and metal-structure non-uniformities can be found. ${ }^{14}$ Moreover, it does not require special magnetization devices and the tested surface does not require a special treatment. Therefore, the MMM technology has been widely applied to inspect pressure vessels, ${ }^{15}$ piping ${ }^{16}$ and other equipment in service. The first pilot results of a fatigue-damage analysis obtained with the BNA and MMM methods have been already reported. ${ }^{17,18}$

In the light of these facts, we performed the BNA and MMM testing on the samples of the chosen unalloyed construction steel, monitoring the future fatigue damage even before the initialization of the magistral crack. Subsequently, we compared the obtained results with theoretical predictions and, finally, we discussed the applicability of these methods.

\section{SAMPLES UNDER INVESTIGATION}

Experimental samples (Figure 1) were made from the unalloyed construction steel S355J2G3 with a chemical composition in mass fractions $(w / \%)$ : $0.2 \mathrm{C}$, $0.55 \mathrm{Si}, 1.6 \mathrm{Mn},<0.035 \mathrm{P}$ and $<0.035 \mathrm{~S}$. It is a commonly used material for welded constructions, machine parts and electrical-apparatus parts that are not strained by high temperature. Samples were manufactured from 6-mm thick plates with the water-jet-machining method to avoid a thermal influence and consequent deformation. The surfaces chosen for the analysis were then

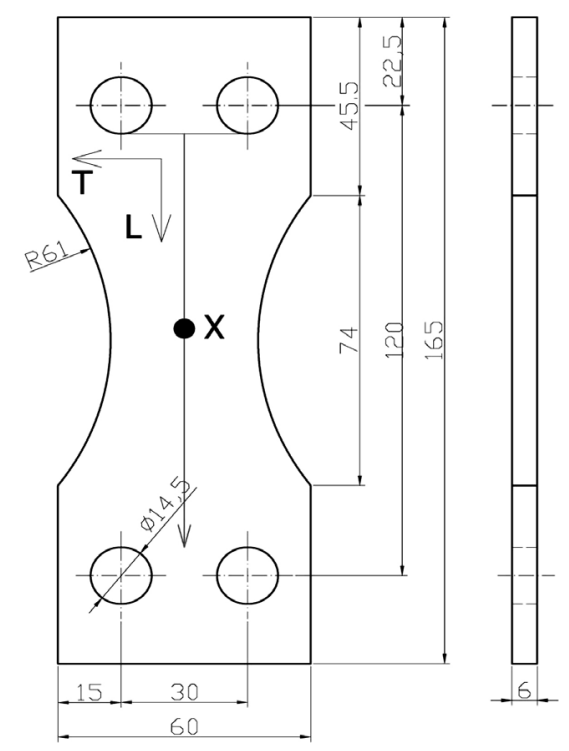

Figure 1: Shape and dimensions of the specimens for fatigue test Slika 1: Oblika in dimenzije preizkušancev za preizkus utrujanja pre-treated with metallographic papers in a range of 240-400-600-800-1200-2500.

In order to restrain the notch effect ${ }^{19}$, sample edges were sharpened and, moreover, polished with a diamond paste with the average grain size of $3 \mu \mathrm{m}$.

\section{EXPERIMENTAL TECHNIQUES}

\subsection{XRD analysis}

XRD measurements were performed with a PROTO iXRD COMBO diffractometer in the $\omega$-goniometer or iso-inclination mode with $\mathrm{Cr}-K \alpha$ radiation. The line $\{211\}$ of the $\alpha$-Fe phase was measured with interplanar lattice spacings computed from the maxima of Pearson VII functions fitted to $\mathrm{Cr}-K \alpha_{1}$ profiles after the $\mathrm{Cr}-K \alpha_{2}$ stripping carried out with the Rachinger method. The stresses were computed presuming the biaxial state of macroscopic residual stresses (RS) using the WinholtzCohen method and X-ray elastic constants $1 / 2 s_{2}=5.76$ $\mathrm{TPa}^{-1},-s_{1}=1.25 \mathrm{TPa}^{-1}$.

\subsection{Barkhausen noise analysis}

Variations of microstructural changes during the loading were also studied using the micro-magnetic testing method. ${ }^{20}$ Magneto-elastic parameter $m p$ was chosen as the characteristic of the surface and subsurface layers. This parameter was determined with the rootmean-square method involving all the measured signal amplitudes and it is given in volts. It was calculated for a specified analysis frequency range. The measurements were performed using a commercial unit Stresstech MicroScan 600-1 magneto-elastic analyser with standard sensors, the $51-138-1501$ type for $m p$ changes during the fatigue test and the $51-171-25-11$ type for the surface characterization after the crack initialization. The main parameters of the applied method had a sinusoidal shape of the magnetic signal, a magnetic voltage of $3.5 \mathrm{~V}$ and a frequency of $75 \mathrm{~Hz}$. The obtained results are the mean values from 10 measurements. The estimation of the penetration depth $\delta$ of the excitation signal depends on the used frequency $f$ and the analysed material (permeability $\mu$ and conductivity $\sigma$ ), in Equation (1). ${ }^{21}$ In practice, a typical expectable effective penetration depth is in a range of up to $20 \mu \mathrm{m}$ for this experimental arrangement in Equation (1):

$$
\delta=\frac{1}{\sqrt{\pi \mu \sigma f}}
$$

\subsection{MMM method}

A TSC-3M-12 instrument was used for the analysis. Probe 1-8E with four sensors was employed. 
K. KOLAŘÍK et al.: USING THE BARKHAUSEN-NOISE ANALYSIS AND METAL-MAGNETIC-MEMORY METHOD ...

\subsection{Fatigue loading}

The bending fatigues tests were performed in a SCHENCK PWYG machine. The loading frequency was $17 \mathrm{~Hz}$. The load ratio was $R=-1$ and the loading force was from $220 \mathrm{MPa}$ to $370 \mathrm{MPa}$. Cycles were required to initiate cracks.

\section{RESULTS AND DISCUSSIONS}

Results of the fatigue test after different loads of the samples are given in Table 1; they are in accordance with the theoretical presumptions. ${ }^{22}$

Table 1: Results of the fatigue test - the number of cycles to crack initialization

Tabela 1: Rezultati preizkušanja utrujanja - število ciklov do nastanka razpoke

\begin{tabular}{|c|c|c|}
\hline Sample & load $(\mathrm{MPa})$ & number of cycles \\
\hline $\mathbf{1}$ & 220 & $\begin{array}{c}4.518 .600 \\
\text { without a crack }\end{array}$ \\
\hline $\mathbf{2}$ & 250 & 698.500 \\
\hline $\mathbf{3}$ & 320 & 600.300 \\
\hline $\mathbf{4}$ & 330 & 288.400 \\
\hline $\mathbf{5}$ & 370 & 82.000 \\
\hline $\mathbf{6}$ & 370 & 67.400 \\
\hline
\end{tabular}

Variations in the magneto-elastic parameters $m p$ at three different loads are shown in Figure 2.

We can see a similar development of the $m p$-function independently of the load forces. This behaviour should be the subject of further study. Generally, the $m p$ development depends on the loading cycles reflecting primarily the changes in the RS. Changes in the

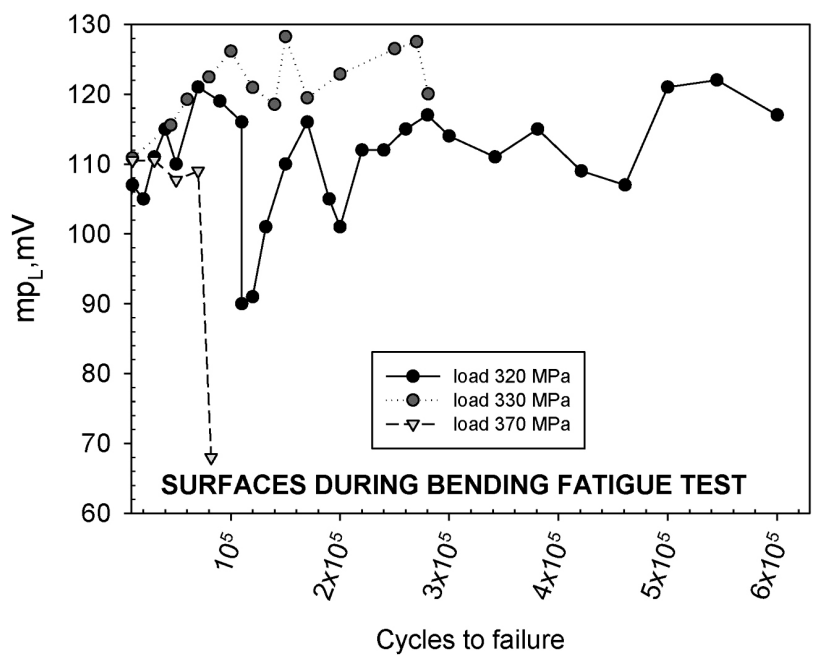

Figure 2: Changes in Barkhausen noise, i.e., parameter $m p$, measured in the middle of a sample (Figure 1), marked with " $\mathrm{X}$ " symbol, in the direction parallel to the loading axis as a function of the loading cycles of the tested specimens

Slika 2: Spreminjanje Barkausnovega hrupa, to je parameter $m p$, merjen na sredini vzorca (Slika 1) označeno z "X" simbolom, v smeri vzporedno z osjo obremenjevanja, v odvisnosti od ciklov obremenjevanja preizkušancev

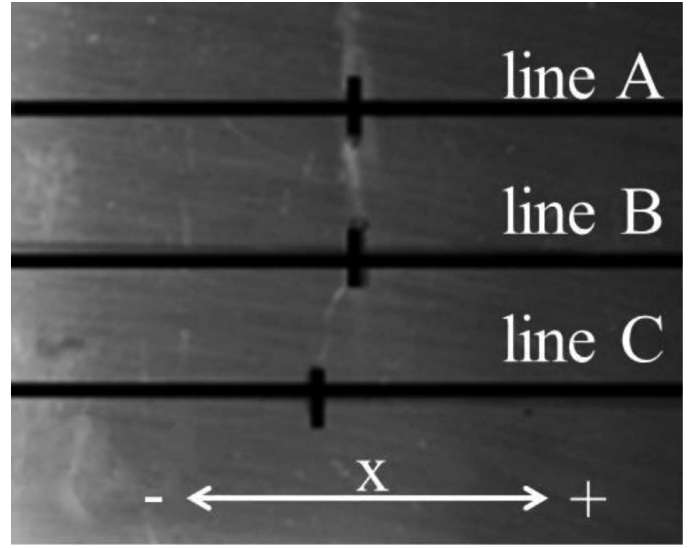

Figure 3: Fatigue crack on the surface of sample 4, the distance between lines is $10 \mathrm{~mm}$

Slika 3: Utrujenostna razpoka na površini vzorca 4, razdalja med linijami je $10 \mathrm{~mm}$

mechanical properties during the loading are determined by the movement of dislocations and their mutual interactions. Dislocation movement is further influenced by the presence of precipitates, foreign particles, grain boundaries, etc. It is, therefore, clear that changes in the configuration and density of dislocations and also changes in the distribution and morphology of other types of obstacles will occur during the cyclic deformation. A greater loading force leads to a higher density of dislocations, $10^{10}$ to $10^{13} \mathrm{~cm}^{-2}$, resulting in an even more significant drop of $m p$. Moreover, the changes in $m p$ reflect the responses of material properties, such as hardening and softening, vacancy concentration and also the mentioned formation of dislocations.

At the start, loading cycles result in a fluctuation of dislocation density, which can be manifested in the changes in the RS as well as in the cyclic softening and hardening of the material. ${ }^{23}$ The latter effects influence the domain wall movement, which leads to increases and decreases of $m p$ for all the loading forces during the

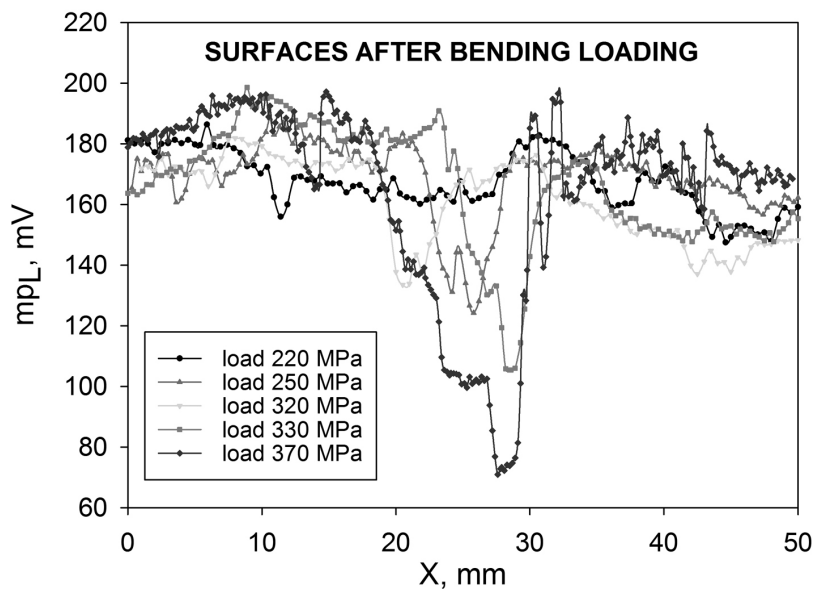

Figure 4: Gradient of $m p$ obtained from the area of crack determined with BNA

Slika 4: Gradient $m p$ dobljen iz področja razpoke, določene z BNA 
K. KOLAŘÍK et al.: USING THE BARKHAUSEN-NOISE ANALYSIS AND METAL-MAGNETIC-MEMORY METHOD ...

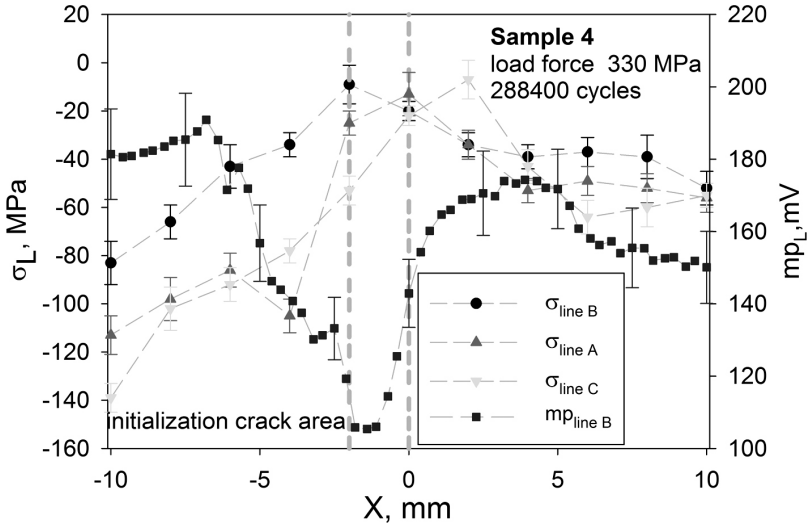

Figure 5: Gradients of RS and $m p$ from the area of crack (Figure 3) determined with XRD and BNA

Slika 5: Gradient RS in mp iz področja razpoke (Slika 3) določena z XRD in BNA

fatigue test. At the end of the fatigue life, $m p$ drops rapidly because of the crack growth (Figures 3 and 4).

Figure 4 shows the $m p$ measured after the cycle loading around the crack area. Because of a high level of plastic deformation and the crack acting as a dielectric, inhomogeneities of the magnetic field and changes in the domain structure of the crack are formed ${ }^{24}$, which lead to a decrease of $m p$. From Figure 4, it is evident that a higher loading force results in larger deformation zones, a larger amount of cracks and, consequently, in a lower value of $m p$. Because of the crack initialization, the RS starts to relax and it reaches its minimum if the cracks are fully developed, as can be seen in Figure $\mathbf{5}$.

During the cycling loading, dislocations move in the material and can gather, which leads to an accumulation of stress in the given areas. Increasing the stress accumulation results in weak changes of the magnetic field. ${ }^{18}$ The final state of this process is an initialization of cracks. These conclusions are consistent with the results presented in Figures 6 and 7, where magneto-

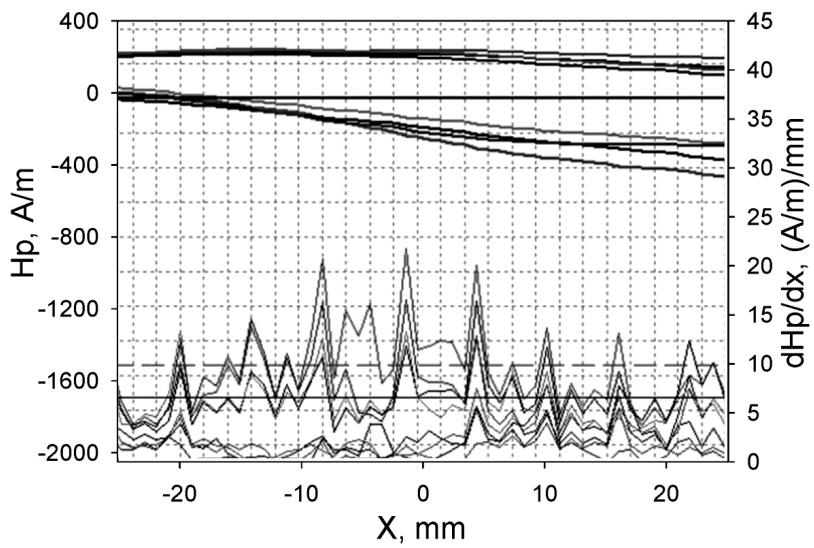

Figure 6: Magnetogram obtained with the MMM method from the surface of sample 1 after the cyclic loading. The lower lines $(\mathrm{dHp} / \mathrm{dx})$ are the partial derivation of the measured upper lines $(\mathrm{Hp})$

Slika 6: Magnetogram, dobljen z MMM metodo iz površine vzorca 1 po cikličnem obremenjevanju. Spodnje linije $(\mathrm{dHp} / \mathrm{dx})$ so parcialna derivacija izmerjenih zgornjih linij (HP)

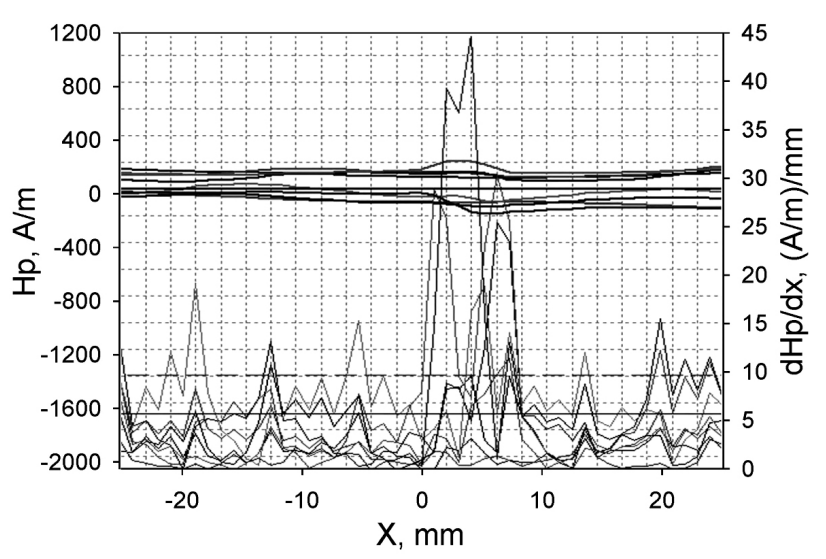

Figure 7: Magnetogram obtained with the MMM method from the surface of sample 4 after the cyclic loading; the lower lines $(\mathrm{dHp} / \mathrm{dx})$ are the partial derivation of the measured upper lines $(\mathrm{Hp})$

Slika 7: Magnetogram, dobljen z MMM metodo iz površine vzorca 4 po cikličnem obremenjevanju, spodnje linije $(\mathrm{dHp} / \mathrm{dx})$ so parcialna derivacija izmerjenih zgornjih linij (Hp)

grams of the samples without and with a crack are presented, respectively. In addition, in Figure 7, a high value of the magnetic-field gradient $(\mathrm{dHp} / \mathrm{dx})$ is evident, which corresponds well with the fatigue-crack presence (Figure 3). The physical nature of the gradual $\mathrm{dHp} / \mathrm{dx}$ increase during the cycling of the analysed surface is related to the secondary domain structure of the ferromagnetic sample. This is produced in the vicinity of defects in the lattice. The increase in the $\mathrm{dHp} / \mathrm{dx}$ amplitude is associated with an increase in the density of the closing domains compensating the dispersive magnetic field in the vicinity of the accumulating defects during the cycling. The sharp increase in $\mathrm{dHp} / \mathrm{dx}$ during the cracking is related to the creation of the closing (secondary) domains, which compensate the dispersive field of the new surface, minimizing the magnetostatic energy of the magnetic sample.

\section{CONCLUSIONS}

The results of the Barkhausen-noise analysis and metal-magnetic-memory testing correspond well with the established theoretical predictions. Moreover, it was found that

- dependence of the magneto-elastic parameter $m p$ on the loading cycles is not monotonous. Nevertheless, mainly before the cracking, it oscillates (Figure 2);

- cracks tend towards an inhomogeneous magnetic field of the material (due to the interruptions of the magnetic line of the force), which leads to an $m p$ reduction (Figure 4). The presence of the cracks causes a relaxation of residual stresses (Figure 5).

- using the metal-magnetic-memory method, it should be possible to analyse fatigue damage before the initialization of the magistral crack (Figures 6 and 7). On the other hand, it is necessary to know the history of the material. 


\section{MATERIALI IN TEHNOLOGIJE/MATERIALS AND TECHNOLOGY (1967-2017) - 50 LET/50 YEARS}

\section{K. KOLAŘíK et al.: USING THE BARKHAUSEN-NOISE ANALYSIS AND METAL-MAGNETIC-MEMORY METHOD ...}

To summarize, we can conclude that the metal-magnetic-memory technique and Barkhausen-noise analysis are advantageous in certain circumstances, for example, for an in-service inspection of structures with complex geometries.

\section{Acknowledgments}

This paper draws on the outcomes of the SGS - 2015 - 016 project: Analysis of Surfaces of Assemblies and Tools by Surface Integrity Method and Impacts on End-Use Properties.

\section{REFERENCES}

${ }^{1}$ J. P. Davim, Surface integrity in machining, Springer, London 2010 , doi:10.1007/978-1-84882-874-2

${ }^{2}$ J. Schijve, Fatigue of structures and materials, Kluwer Academic Publisher, Dordrecht 2001, 513, doi:10.1007/0-306-48396-3

${ }^{3}$ R. G. Govindaraju, A. Strom, D. C. Jiles, S. B. Biner, Evaluation of low-cycle fatigue damage in steel structural components by magnetic measurement technique, Review of Progress in Quantitative Nondestructive Evaluation, New York, 1993, 1839-1846, doi:10.1007/978-1-4615-2848-7_236

${ }^{4}$ M. Witos, M. Zokowski, Passive Magnetic Observer in NDE \& SHM Applications, EWSHM-7th European Workshop on Structural Health Monitoring, France, 2014, 213-220

${ }^{5}$ Y. Tomita, K. Hashimoto, N. Osawa, Nondestructive estimation of fatigue damage for steel by Barkhausen noise analysis, NDT \& E International, 29 (1996) 5, 275-280, doi:10.1016/S0963-8695(96) 00030-8

${ }^{6} \mathrm{~K}$. Tiitto, Use of Barkhausen noise in fatigue, Nondestructive Testing and Evaluation, 5 (1989) 1, 27-37, doi:10.1080/02780898908952952

${ }^{7}$ V. T. Vlasov, A. A. Dubov, Development of theory of ferromagnetic domain structure by the example of iron, Proceedings of the third international conference Diagnostics of equipment and structures with usage of metal magnetic memory, Moscow, 2003

${ }^{8}$ A. A. Dubov, S. M. Kolokolnikov, Method of metal magnetic memory (MMM) and inspection devices: Training handbook, Tisso Co, Moscow 2003, 320

${ }^{9}$ Q. Xin, D. Shu, L. Hui, W. Wei, J. Chen, Magnetic Barkhausen noise, metal magnetic memory testing and estimation of the ship plate welded structure stress, Journal of Nondestructive Evaluation, 31 (2012) 1, 80-89, doi:10.1007/s10921-011-0123-7

${ }^{10}$ B. Hu, G. Gan, S. Gongtian, L. Luming, C. Xing, Study on Magnetic Memory Method (MMM) for Fatigue Evaluation, Proc. of 17 th World Conference on Nondestructive Testing, China, 2008, 25-28
${ }^{11}$ J. Čížek, M. Neslušan, M. Čilliková, A. Mičietová, O. Melikhova, Modification of steel surfaces induced by turning: non-destructive characterization using Barkhausen noise and positron annihilation, Applied Physics, 47 (2014) 44, 445301

${ }^{12}$ A. A. Dubov, A study of metal properties using the method of magnetic memory, Metal Science and Heat Treatment, 39 (1997) 9, 401-405, doi:10.1007/BF02469065

${ }^{13}$ A. A. Dubov, Principle features of metal magnetic memory method and inspection tools as compared to known magnetic NDT methods, CINDE Journal, 27 (2006) 3, 16-20

${ }^{14}$ X. Hai Yan, X. M. Qiang, Y. Zhijun, Z. Lihong, Stress State Analysis of Failure Blade with MMM Method, Daqing Petroleum Institute China, 2006

${ }^{15}$ O. Stupakov, T. Toshiyuki, K. Kolařík, Barkhausen Noise Testing of Residual Stresses Introduced by Surface Hardening Techniques, Electromagnetic Nondestructive Evaluation (XVII), 39 (2014), 288-295, doi:10.3233/978-1-61499-407-7-288

${ }^{16}$ J. W. Wilson, G. Y. Tian, S. Barrans, Residual magnetic field sensing for stress measurement, Sensors and Actuators A: Physical, 135 (2007) 2, 381-387, doi:10.1016/j.sna.2006.08.010

${ }^{17} \mathrm{G}$. Pluvinage, Notch effect in fatigue and fracture, Springer, Netherlands 2001, 22, doi:10.1007/978-94-010-0880-8_1

${ }^{18}$ W. A. Theiner, Physical Basis of Micromagnetic Methods and Sensor Systems and their Application Areas, Proceedings of the 1st International Conference on Barkhausen noise and Micromagnetic Testing, Hannover, 1998, 197-218

${ }^{19}$ W. A. Theiner, E. Brinksmeier, E. Stücker, Stress Measurements on Components with Nondestructive Ferromagnetic Methods, Residual Stresses in Science and Technology, 1 (1987), 167-174

${ }^{20}$ M. Lindgren, T. Lepistö, Effect of cyclic deformation on Barkhausen noise in a mild steel, NDT \& E International, 36 (2003) 6, 401-409, doi:10.1016/S0963-8695(03)00031-8

${ }^{21}$ S. Tiitto, R.Säynäjäkangas, Spectral damping in Barkhausen noise, IEEE Transactions on Magnetics, 11 (1975) 6, 1666-1672, doi:10.1109/TMAG.1975.1058960

${ }^{22}$ W. Guan, P. Guo, C. Xuedong, Metal Magnetic Memory Testing Technique for Typical Defects in Pressure Vessels and Pipelines, ASME 2015 Pressure Vessels and Piping Conference, American Society of Mechanical Engineers, 2015, doi:10.1115/PVP201545826

${ }^{23}$ L. Faturík, L. Trško, S. Hrček, O. Bokůvka, Comparison of Structural Design in High and Ultra-High Cycle Fatigue Regions, Transactions of FAMENA, 38 (2015) 4, 1-12

${ }^{24}$ M. Neslušan, J. Majerík, P. Kejzlar, M. Čilliková, A. Mičietová, Barkhausen Noise Emission in Hard Milled Surfaces of Steel C55, Transactions of FAMENA, 39 (2016) 4, 55-64 